\title{
Contribution of $\mathrm{CD4}^{+} \mathrm{T}$ cells to the early mechanisms of ischemia- reperfusion injury in a mouse model of acute renal failure
}

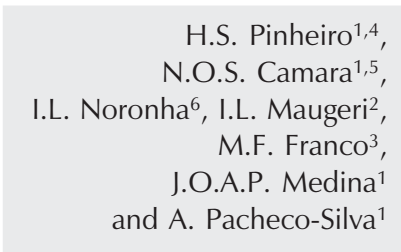

\begin{abstract}
'Divisão de Nefrologia, ${ }^{2}$ Divisão de Imunologia, ${ }^{3}$ Divisão de Patologia, Escola Paulista de Medicina, Universidade Federal de São Paulo, São Paulo, SP, Brasil ${ }^{4}$ Divisão de Nefrologia, Universidade Federal de Juiz de Fora, Juiz de Fora, MG, Brasil ${ }^{5}$ Departamento de Imunologia, ${ }^{6}$ Divisão de Nefrologia, Universidade de São Paulo, São Paulo, SP, Brasil
\end{abstract}

Correspondence

H.S. Pinheiro

Divisão de Nefrologia

Universidade Federal de Juiz de Fora Rua Benjamin Constant, 1073/401

36015-400 Juiz de Fora, MG

Brasil

E-mail: helady@terra.com.br

Research supported by FAPESP (Nos. 04/13826-5 and 04/08311-6).

H.S. Pinheiro was the recipient

of a CAPES fellowship.

Received March 17, 2006 Accepted January 16, 2007 ......................

\begin{abstract}
Renal ischemia-reperfusion (IR) injury is the major cause of acute renal failure in native and transplanted kidneys. Mononuclear leukocytes have been reported in renal tissue as part of the innate and adaptive responses triggered by IR. We investigated the participation of $\mathrm{CD}^{+} \mathrm{T}$ lymphocytes in the pathogenesis of renal IR injury. Male mice (C57BL/6, 8 to 12 weeks old) were submitted to $45 \mathrm{~min}$ of ischemia by renal pedicle clamping followed by reperfusion. We evaluated the role of $\mathrm{CD}^{+} \mathrm{T}$ cells using a monoclonal depleting antibody against CD4 (GK1.5, $50 \mu$, ip), and class II-major histocompatibility complex molecule knockout mice. Both CD4-depleted groups showed a marked improvement in renal function compared to the ischemic group, despite the fact that GK1.5 mAb treatment promoted a profound CD4 depletion (to less than 5\% compared to normal controls) only within the first $24 \mathrm{~h}$ after IR. CD4-depleted groups presented a significant improvement in 5-day survival (84 vs 80 vs $39 \%$; antibody treated, knockout mice and non-depleted groups, respectively) and also a significant reduction in the tubular necrosis area with an early tubular regeneration pattern. The peak of CD4positive cell infiltration occurred on day 2, coinciding with the high expression of $B C$ mRNA and increased urea levels. CD4 depletion did not alter the $\mathrm{CD} 11 \mathrm{~b}$ infiltrate or the IFN- $\gamma$ and granzyme-B mRNA expression in renal tissue. These data indicate that a $\mathrm{CD} 4^{+}$subset of $\mathrm{T}$ lymphocytes may be implicated as key mediators of very early inflammatory responses after renal IR injury and that targeting CD4 ${ }^{+}$ $\mathrm{T}$ lymphocytes may yield novel therapies.
\end{abstract}

Key words

- Ischemia-reperfusion

- Kidney inflammation

- Leukocytes

- $\mathrm{CD}^{+}$T lymphocytes

- Kidney transplantation

- Acute renal failure

....................

\section{Introduction}

Ischemia-reperfusion (IR) injury is inevitably associated with the retrieval, stor- age and transplantation of solid organs, especially with grafts from deceased donors (1). IR injury adversely affects early renal graft function and contributes to the devel- 
opment of chronic allograft nephropathy $(2,3)$. Furthermore, in native kidneys, mortality of patients with ischemic acute renal failure has remained high over the last 50 years despite enormous advances in supportive care (4). Currently, there is no effective therapeutic approach to limit IR, so that knowledge of its pathophysiology is crucial to devise effective strategies.

Many studies have shown that the inflammatory response induced by ischemia followed by reperfusion is largely responsible for the tissue damage, consequently leading to functional organ failure (3,5-7). This acute inflammatory response is characterized by the induction of a pro-inflammatory cytokine cascade (8), enhanced expression of adhesion molecules $(5,8)$, up-regulation of the major histocompatibility complex (MHC) antigens, and cellular infiltration (5-7,8,9). However, the specific mechanism involved in inflammation-mediated IR injury is still a matter of debate $(1,9)$. Neutrophils have long been related to the ischemic tissue damage. The inhibition of neutrophil migration and even their activation have been demonstrated to have a protective effect on renal IR $(5,9)$. However, these data were not unanimously accepted and the role of neutrophils in tissue aggression is currently considered to be less important $(9,10$ 12).

On the other hand, there is some evidence implicating lymphocytes as important mediators in IR injury. Notwithstanding the presence of T lymphocytes in ischemic tissues $(7,11,12)$, the mechanisms involved in tissue injury are not known.

The idea that $\mathrm{T}$ lymphocytes are important in IR came from classical studies on biopsies from patients with acute ischemic renal failure where mononuclear cells predominated in the vasa recta (13). Furthermore, the production of $\mathrm{T}$ cell-associated cytokines and chemokines has also been well documented at sites of experimental renal IR damage $(7,8,10)$. Blockade of leukocyte adhesion molecules such as intercel- lular adhesion molecule-1 and CD11/CD18 promotes substantial reduction of IR injury $(5,14)$. Moreover, blockade of the CD28-B7 co-stimulatory pathway with CTLA4-Ig or anti-B71 antibody significantly reduces renal dysfunction after IR in rats $(7,11,15,16)$. The use of gene-targeted knockout mice has brought more detailed information about the role of $\mathrm{T}$ cells in this context. $\mathrm{CD}^{+}$and $\mathrm{CD}^{+} \mathrm{T}$ cell double-knockout mice, nu/nu mice (deficient in T cells) and CD4-knockout mice are all protected from renal IR injury $(17,18)$. Furthermore, adoptive transfer of naive CD4 $\mathrm{T}$ cells into these mice reconstituted the injury profile, which was mainly dependent on interferon- $\gamma$ (IFN- $\gamma$ ) and CD28 pathways (18).

Therefore, it is well accepted that IR is an orchestrated event involving innate and adaptive immune responses (12). The amplification of the immune response as an early event might elicit a strong $\mathrm{T}$ cell action that ultimately results in extension of the tissue injury. We hypothesized that the early initial phase post-IR injury is a critical moment of $\mathrm{T}$ cell activation contributing to the pathophysiology of acute renal damage. We addressed this issue in a murine model of renal IR injury, in which the animals underwent acute and transient CD4 T cell depletion. Additionally, class II MHC knockout mice, which are naturally $\mathrm{CD} 4{ }^{+} \mathrm{T}$ cell depleted, were also used in the experiments. We investigated the profile of histological damage and the involvement of pro-inflammatory cytokines.

\section{Material and Methods}

\section{Reagents}

The following antibodies were used in fluorescence-activated cell sorting (FACS) experiments: anti-CD3 (clone 145-2C11, hamster anti-mouse IgG1, fluorescein 5-isothiocyanate), anti-CD4 (RM-5, rat anti-mouse IgG2b, phycoerythrin), all purchased from Pharmin- 
gen (San Diego, CA, USA). For immunohistochemistry, the primary biotinylated monoclonal antibodies (mAb) used were GK1.5 (rat anti-mouse CD4) and M1/70 (rat anti-mouse CD11b-macrophages, natural killer (NK) cells and dendritic cells) (Pharmingen).

\section{Animals}

Isogenic male $\mathrm{C} 57 \mathrm{BL} / 6$ mice $\left(\mathrm{H} 2^{\mathrm{b}}\right)$ were obtained from the Institute of Pharmacology, Universidade Federal de São Paulo. MHC class II Ab-deficient mice were purchased from Taconic Farms (Germantown, NY, USA). These mice were derived by homologous recombination in embryonic stem cells as described (19). They exhibit depletion of $\mathrm{CD}^{+} \mathrm{T}$ cells by the disruption of the $\mathrm{A} \beta$ $\left(\mathrm{H} 2^{\mathrm{b}}\right)$ gene. The animals were 8-12 weeks old and weighed 25-28 g. All animals were housed in individual standard laboratory cages and had free access to water and food.

\section{Depletion of $\mathrm{CD}^{+}$cells}

A purified mAb against L3T4 (GK1.5, rat $\operatorname{IgG} 2 b$ ) was purchased from Pharmingen and selected mice were injected with a single dose of $50 \mu \mathrm{g}$ ip $48 \mathrm{~h}$ before IR. CD $4^{+}$ lymphocyte depletion by anti-CD4 ${ }^{+} \mathrm{T}$ cell $\mathrm{mAb}$ was confirmed by FACS analyses of splenocytes on days $+1,+2$ and +3 posttreatment, corresponding to the day of pedicle clamping, 1 and 2 days after reperfusion, respectively. The anti-CD4 treatment promoted a profound depletion of $\mathrm{CD} 4^{+} \mathrm{T}$ cells from the splenocyte population compared to untreated animals. At the time of pedicle clamping, $48 \mathrm{~h}$ after the administration of antibodies, $96.9 \pm 1.8 \%$ of $\mathrm{CD}^{+}$cells were depleted compared to control animals. Three and 4 days after GK1.5 administration (24 and $48 \mathrm{~h}$ after pedicle clamping) there was a partial splenic repopulation, and the depletion was $68.5 \pm 2.1$ and $66.7 \pm 6.3 \%$ in matched controls. The MHC class II knockout animals had only $3.6 \%$ of $\mathrm{CD}^{+}{ }^{+} \mathrm{T}$ cells in the splenocyte population (depletion of 96.5 $\pm 0.7 \%$ ). A schematic summary of FACS results is shown in Figure 1. The FACS analyses were carried out in a Becton Dickinson FACScalibur (Mountain View, CA, USA) and the results analyzed with Cell Quest program (Becton Dickinson).

\section{Ischemia-reperfusion model and protocol}

Surgery was performed as described (5). Briefly, mice were anesthetized, placed on a surgical table and heated by indirect illumination. A midline abdominal incision was made and both renal pedicles were crossclamped for $45 \mathrm{~min}$. Both kidneys were inspected after 2 min to confirm the change in color and thus ischemia. The abdomen was filled with $500 \mu \mathrm{L}$ of prewarmed sterile saline solution just before being temporarily closed. The abdomen was reopened and the microsurgery clamps were removed. The kidneys were inspected for complete restoration of blood flow and $500 \mu \mathrm{L}$ of prewarmed sterile saline was again instilled into the abdomen. The abdomen was closed, and the animals were placed in heated cages until complete recovery from anesthesia, with free access to water and food. Animals were divided into four groups: group $1(\mathrm{G} 1, \mathrm{~N}=$ 9 ), surgery without pedicle clamping (sham); group $2(\mathrm{G} 2, \mathrm{~N}=25), 45 \mathrm{~min}$ of ischemia followed by reperfusion; group 3 (G3, N = 28), animals submitted to IR and treated with $50 \mu \mathrm{g}$ GK1.5 $48 \mathrm{~h}$ before the procedure, and group $4(\mathrm{G} 4, \mathrm{~N}=10)$, genetically depleted animals submitted to IR. Group 1, 2 and 3 mice were killed 1, 2 and 5 days after surgery. In group 4 , because of the limited number of animals available, we decided to evaluate the points of major renal injury ( 2 days) and the point of almost recovery ( 5 days). At that time, blood was collected for urea measurement and kidney tissue was harvested for histological study and messenger RNA (mRNA) analysis. All procedures were carried out with the approval of the 
Research Ethics Committee of Universidade Federal de São Paulo.

\section{Renal function}

Blood samples $(400 \mu \mathrm{L})$ were collected by retro-orbital puncture under general anesthesia. Serum urea measurements were performed in duplicate by the urease method using a Cobas Mira Plus autoanalyzer (Roche, Mannheim, Germany).

\section{Mortality}

Mortality is reported as percentage of deaths in comparison to the total number of animals submitted to the surgical procedure in each group at two times (days 1 and 2 after surgery). Survival curves were used to report mortality five days after the IR procedure.

\section{Histological examination}

After surgical removal, kidneys were cut coronally, fixed in Bouin solution followed by $10 \%$ buffered formalin and embedded in paraffin. Sections $(4 \mu \mathrm{m})$ were stained with hematoxylin-eosin. The extent of tubular morphology patterns of necrosis and regeneration in the outer medulla was examined by blinded morphometry assessment using a computed-assisted image system with an Olympus BX40F-3 microscope (Olympus Optical Company, Tokyo, Japan) and the Image Pro Plus for Windows 3.0 software (Media Cybernetic, Silver Spring, MD, USA). After image capture by this system, the morphometric quantitative analysis was performed with the Image Lab software (Image Lab, São Paulo, SP, Brazil). In these studies, the area of necrosis or regeneration was traced by computed-assisted morphometry and the results are reported as percent necrosis or regeneration in the total area $\left(0.073 \mathrm{~mm}^{2}\right)$ of the $200 \mathrm{X}$ field of view. For this purpose, a total area of $1.46 \mathrm{~mm}^{2}$ (20 fields, 200X) per specimen was analyzed in four animals per group. A tubular necrosis pattern was assigned when there was a loss of membrane and nuclear integrity, loss of brush border, vacuolization of tubular epithelial cells, or the presence of intratubular debris. Regeneration profiles were assigned when we observed soft nuclear chromatin, nucleus of various shapes and volumes, many nucleoli per nucleus, and a less basophilic cytoplasm (13).

\section{Immunohistochemistry}

Surgically removed kidney sections were snap frozen in liquid nitrogen and embedded in Histo Prep (Fisher Diagnostics, Fair Lawn, NJ, USA). Thin frozen sections $(5 \mu \mathrm{m})$ were cut and fixed in $2 \%$ methanol. The binding of mAb was detected by the avidin-biotin/ alkaline phosphatase method as described (20). We used proliferating cell nuclear antigen (PCNA) identification to identify cells undergoing the proliferating phase. For this purpose paraffin sections were prepared as described (20). As the PC10-EPOS antibody obtained from Dako (Dako A/S, Glostrup, Denmark) is conjugated with peroxidase, sections were directly incubated with aminoethyl-carbazole (Sigma, St. Louis, MO, USA). Labeled cells in the outer medulla in 20 consecutive, non-overlapping fields per mouse, were counted in 3 animals per group using the same computed image system as used for histological evaluation. For PCNA analysis we measured fields of $200 \mathrm{X}$ and of 400X for $\mathrm{CD}^{+}{ }^{+}$and CD11b-positive cells. All sections were evaluated blindly.

\section{Reverse transcriptase-polymerase chain reaction}

Kidney samples were quickly frozen in liquid nitrogen immediately after surgical excision under sterile conditions. Total RNA from renal tissues was extracted using TRIzol LS reagent (Life Technologies, New York, 
NY, USA) according to the manufacturer's protocol. Three animals per group were evaluated for each time point. mRNA was extracted from total RNA using the QuickPrep Micro mRNA Purification kit (Amersham Pharmacia Biotech Inc., Piscataway, NJ, USA) following manufacturer instructions. Samples of 100-200 ng of kidney mRNA and PHA- and PMA-stimulated spleen cell mRNA (as external control) were added to oligo $\mathrm{d}(\mathrm{T})$, and a reverse transcriptase reaction was carried out with nucleotides dATP, dCTP, dGTP, DTTP $(10 \mathrm{mM}$ each), and M-MLV reverse transcriptase (Gibco BRL Life Technologies, Gaithersburg, MD, USA) (21). Primers were constructed based on published sequences for the constant-conserved residues of $\beta$-chain $(B C)$ as a marker of the presence of $\mathrm{T}$ cells and for IFN- $\gamma$ and granzyme B as products related to $\mathrm{T}$ cell function and for $\mathrm{B}$-actin as an internal control of the presence and quality of mRNA (21). A polymerase chain reaction (PCR) assay was performed with cDNA, $2.5 \mathrm{U}$ of Taq polymerase (Gibco) and specific primers for a $50-\mu \mathrm{L}$ final reaction. Forty cycles of amplification were performed. Each cycle consisted of $1 \mathrm{~min}$ at $94^{\circ} \mathrm{C}$ for denaturation, a specific annealing cycle $(45 \mathrm{~s}$ at $55^{\circ} \mathrm{C}$ for $\mathrm{B}$-actin and $\mathrm{BC}, 45 \mathrm{~s}$ at $57^{\circ} \mathrm{C}$ for granzyme $\mathrm{B}$, and $30 \mathrm{~s}$ at $53^{\circ} \mathrm{C}$ for IFN- $\gamma$ ) and $45 \mathrm{~s}$ of $72^{\circ} \mathrm{C}$ for extension, followed by a final incubation at $72^{\circ} \mathrm{C}$ for $10 \mathrm{~min}$. PCR conditions were standardized for sensitivity, reliability and specificity with the negative and positive controls. The PCR product was run on 2\% agarose gel stained with fluorescent dye (Sybr Green, Molecular Probes, Eugene, OR, USA). The gels were scanned to estimate relative band intensity using a Storm ${ }^{\mathrm{TM}}$ fluorescent optic scanner and Image Quant 4.0 software (Molecular Dynamics, Sunnyvale, CA, USA). RNA was estimated semi-quantitatively with $B$-actin ( $B C$, IFN- $\gamma$ ) or $B C$ (granzyme B) as internal control. The results are reported as arbitrary units, expressing the rate of the gene densities com- pared to the internal control ( $(B$-actin or $B C$ ).

\section{Statistical analysis}

Data are reported as means \pm SD (parametric variables) or median and range whenever appropriate. Different evolutions were compared between groups by ANOVA followed by the Student-Newman-Keuls or Dunn test for individual comparisons between groups. The mortality rates at 1 and 2 days after IR were compared by Fisher exact test. Five-day Kaplan-Meier survival curves were compared by the log-rank test. The level of significance was set at $\mathrm{P}<0.05$ for all analyses.

\section{Results}

Transient depletion of CD4 ${ }^{+} \mathrm{T}$ cells promoted renal function protection after ischemia-reperfusion

To demonstrate the importance of $\mathrm{CD} 4^{+}$ $\mathrm{T}$ cells in the inflammatory events of postreperfusion we compared a chronic and sustained depletion of $\mathrm{CD}^{+}{ }^{+} \mathrm{T}$ cells with an acute, profound, but transient depletion. Mice treated with a single 50- $\mu$ g dose of purified GK1.5 mAb were successfully depleted of $\mathrm{CD}^{+}{ }^{+} \mathrm{T}$ cells $48 \mathrm{~h}$ thereafter (population of $3.1 \%$ ), specifically at the time when renal pedicles were clamped (Figure 1). This de-

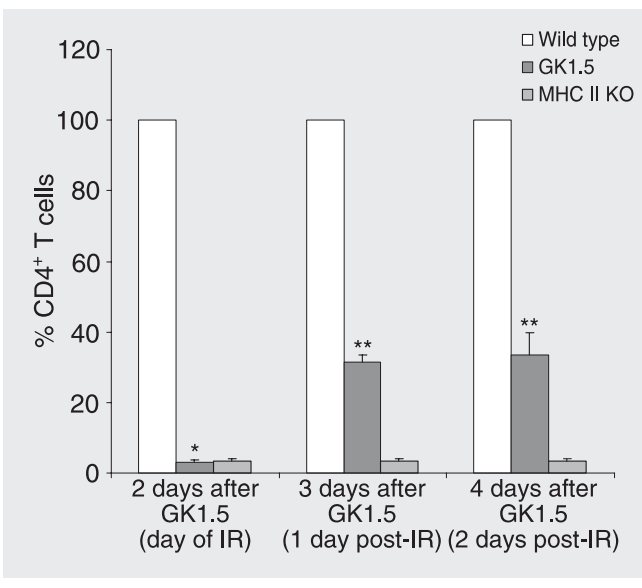

Figure 1. Depletion of splenocyte CD4+ cells. Treatment with GK1.5 mAb (filled columns) promoted a significant reduction of CD4 ${ }^{+}$cells (to $3.1 \%$ ) compared to control (open columns) during mouse ischemia-reperfusion (IR) episode. A subsequent partial repopulation of $\mathrm{CD} 4^{+}$cells $(26$ and $38 \%$ ) occurred on the 2 nd and 3 rd days after IR injury. $\mathrm{CD}^{+}$splenocyte counts in $\mathrm{MHC}$ class II knock-out mice (MHC II $\mathrm{KO} ; 3-4 \%$, grey bars) were similar to those of GK1.5-treated mice at the time of IR. The variation in the values of the control wild-type mouse used as reference was less than $2 \% . \mathrm{N}=3$ in each group. ${ }^{*} \mathrm{P}<0.001$ for the GK1.5 group and MHC II KO group vs control group on day of IR. ${ }^{*} \mathrm{P}<0.01$ for the GK1.5 and MHC II KO groups vs the control group on 2nd and 3rd days after IR (Student $t$-test). 


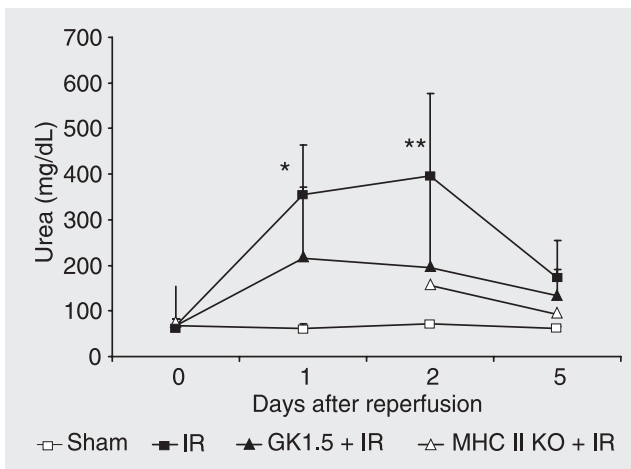

Figure 2. Effect of $\mathrm{CD}^{+}$cell depletion on renal function (urea) after ischemia-reperfusion (IR). Animals of the CD4+-depleted groups treated with GK1.5 (filled triangles, $\mathrm{N}=8$ on day $1, \mathrm{~N}=9$ on day 2 and $\mathrm{N}=11$ on day 5), and $\mathrm{MHC}$ class II knock-out (MHC II KO) animals (open triangles, $\mathrm{N}=6$ on day 2 and $\mathrm{N}=4$ on day 5) produced less urea than the ischemic group (filled squares, $\mathrm{N}=9$ on day $1, \mathrm{~N}=8$ on day 2 and $\mathrm{N}=8$ on day 5) after the same IR injury 1 and 2 days after reperfusion. Sham group (open squares, $\mathrm{N}=3$ on each point). Blood samples were obtained at sacrifice and each point represents a separate group of mice. ${ }^{*} \mathrm{P}<$ 0.05 for the GK1.5 group vs the ischemic group on day 1. ${ }^{* *} \mathrm{P}<0.05$ for the GK1.5 and MHC II KO groups vs the ischemic group on day 2 (ANOVA test with Student-Newman-Keuls correction).

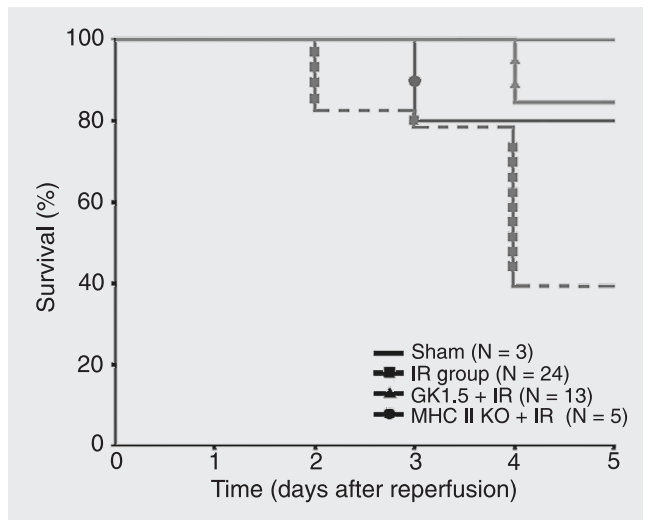

Figure 3. Effect of ischemia-reperfusion (IR) on survival of normal (C57BL/6, dashed line with squares) and $\mathrm{CD}^{+}$cell-depleted animals (GK1.5 treated, triangles, and $\mathrm{MHC}$ II knock-out (MHC II KO), circle). The antiCD4-treated group showed a better survival compared to the ischemic group $(\mathrm{P}<0.01)$ whereas the $\mathrm{MHC}$ II $\mathrm{KO}$ group showed an improved survival $(80.0 \%)$, but without statistical significance. Five-day survival curves were calculated by the Kaplan-Meier method and compared by the log-rank test. All sham-operated animals survived the experiment (black line without symbols). gree of depletion is similar to those achieved in renal transplantation in order to prevent acute rejection and was also reported to protect animals from IR injury (22). GK1.5 mAb-treated animals had a partial reconstitution of the $\mathrm{CD}^{+}{ }^{+} \mathrm{T}$ cell population on days 1 and 2 after reperfusion, ranging from 26 to $38 \%$ of the values observed in matched controls. In contrast, MHC class II knockout mice, genetically deficient in $\mathrm{CD} 4^{+} \mathrm{T}$ cells by negative thymic selection, exhibited a sustained $\mathrm{CD} 4^{+} \mathrm{T}$ cell depletion (population of $3-4 \%$ ), similar to that seen in GK1.5 mAb-treated animals on the day of IR.

Forty-five minutes of ischemia followed by reperfusion caused a marked decrease in renal function as assessed by urea levels in wild-type mice. One day after IR, the animals had a significant increase in blood urea levels as compared to sham-operated animals $(354.5 \pm 109.1$ vs $61.1 \pm 10.7 \mathrm{mg} / \mathrm{dL}, \mathrm{P}$ $<0.05)$. This increase in blood urea peaked on the second day after IR, with an important recovery on day 5 . $\mathrm{CD}^{+} \mathrm{T}$ cell-depleted animals, that had a depletion of the $\mathrm{CD} 4^{+} \mathrm{T}$ cell population, had lower levels of urea on day 1 (G3 - anti-CD4 treated, $215.2 \pm 155.9$ vs G2 - IR animals, $354.5 \pm 109.1 \mathrm{mg} / \mathrm{dL}, \mathrm{P}$ $<0.05)$ and on day $2(\mathrm{G} 3,199.4 \pm 195.9$ and G4 - anti-CD4 treated and genetically depleted, $156.3 \pm 79.2 v s \mathrm{G} 2,396.1 \pm 86.1 \mathrm{mg} /$ $\mathrm{dL}, \mathrm{P}<0.05$ ), when compared to IR animals. Two days after IR injury, although G3 had a partial repopulation of $\mathrm{CD}^{+} \mathrm{T}$ cells (depletion of $68.5 \pm 2.1 \%$ ) compared to knockout mice (depletion of $96.5 \pm 0.7 \%$ ), renal function did not differ between them. Five days after IR, there was no difference among the four groups (Figure 2).

\section{Transient $\mathrm{CD}^{+}{ }^{+} \mathrm{T}$ cell depletion was} associated with increased animal survival after ischemia-reperfusion

This model of IR injury is accompanied by severe acute renal failure that can be indirectly measured by mouse mortality. The 
mortality rate at 1 and 2 days after reperfusion was less than $10 \%$, and did not differ among groups. However, 45 min of ischemia was accompanied by a high-mortality rate in the ischemic group (G2) at 5 days after reperfusion. Five-day animal survival increased in antibody-depleted animals (G3, $84 \%$ ), and in class II MHC KO mice (G4, $80 \%$ ), in contrast to $39 \%$ in the ischemic group $(\mathrm{P}<0.01)$. The survival of $\mathrm{CD}^{+} \mathrm{T}$ cell-depleted groups was statistically similar $(P=0.73)$. None of the animals in the sham group died, suggesting that the surgical procedure was not a cause of death in the model (Figure 3).

The absence of $\mathrm{CD4}^{+} \mathrm{T}$ cells was associated with less acute tubular injury and an early tubular regeneration pattern after ischemiareperfusion

In contrast to acute renal failure in humans, when marked morphological features of tubular necrosis are frequently dissociated from the degree of renal dysfunction, in mice, $45 \mathrm{~min}$ of renal ischemia promoted extensive tubular necrosis in the outer medulla, as can be seen in Figure 4, panel A. The renal function protection seen in animals in which the $\mathrm{CD}^{+} \mathrm{T}$ cell population was absent was mirrored by histological changes in kidney sections on days 1 and 2 . As shown in Figure 4, panel A, on day 2 untreated animals exhibited massive tubular necrosis and obstruction, which were much reduced when the animals were pretreated with GK1.5 (panel B) or in class II MHC KO mice. At this point, in the ischemic group (G2), tubular massive necrosis was predominant, while $\mathrm{CD}^{+}{ }^{+} \mathrm{T}$ cell-depleted animals showing necrotic changes mixed with early regeneration patterns.

Using an accurate morphometric analysis of renal cross-sections, we were able to quantify these differences. One day after reperfusion, the area occupied by necrotic changes in the outer medulla was $67.3 \%$ of the total area measured $\left(1.4 \mathrm{~mm}^{2}\right.$ in 20 fields of view) in G3, significantly smaller than the area of $78.2 \%$ in the ischemic group $(\mathrm{P}<$ $0.05)$. On day 2 , both depleted groups, G3 (37.2\%) and G4 (60.3\%), also had a significant reduction in the tubular necrosis area compared to G2 $(77.6 \%, \mathrm{P}<0.05)$ (Figure 5, panel A).

Another striking difference between CD4 ${ }^{+} \mathrm{T}$ cell-depleted (G3 and G4) and nondepleted ischemic animals after IR injury was the pattern of tubular regeneration, which occurred much earlier in the two depleted groups than in non-depleted ischemic animals (G2). By morphometric analysis we detected this regenerative pattern in $\mathrm{G} 2$ only on day 5 (70.7\% of the total area analyzed). In contrast, in the GK1.5 mAb-treated group (G3), a tubular regeneration area was already present and larger than that of the ischemic group on day 1 after IR (32.6 vs $6.7 \%$, respectively, $\mathrm{P}<0.05$ ). On day 2 , we observed extensive areas of tubular regeneration in $\mathrm{G} 3$ (43.2\%) and G4 (39.6\%), again,

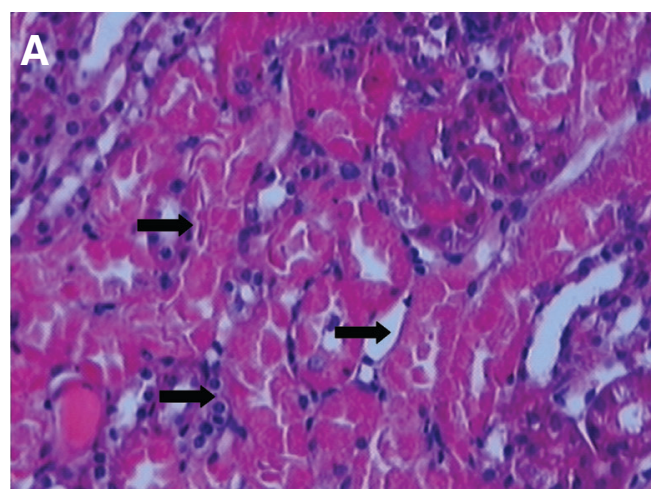

Figure 4. Effect of $\mathrm{CD} 4^{+}$cell depletion on renal histology after $45 \mathrm{~min}$ of ischemia followed by reperfusion. Light microscopy of representative kidney sections, H\&E, 200X. Comparison of animal from the ischemic group $(A)$ and animal treated with antiCD4 mAb (B). Note extensive tubular necrosis (black arrows) in $A$, attenuated in $B$, and $a b-$ sence of regeneration changes in $A$, widespread in $B$ (white arrows).

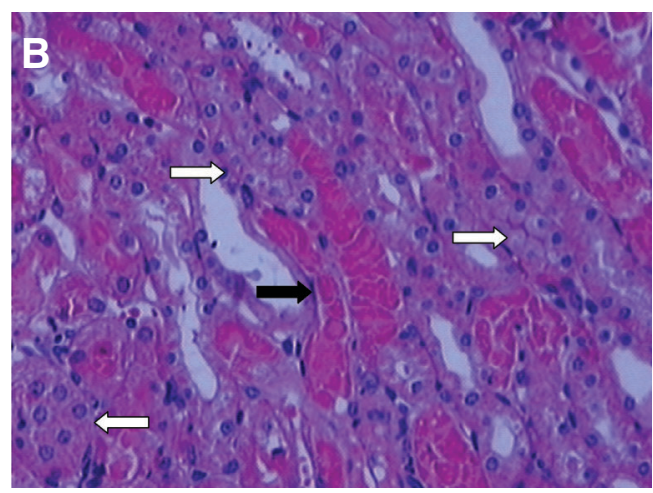


much larger than those observed in the ischemic group $(2.7 \%, \mathrm{P}<0.05)$. The ischemic group showed large areas of tubular regeneration only on day 5 (70.7\%), which were larger than those observed in G3 (39.9\%) and G4 (60.5\%, $\mathrm{P}<0.001$ (Figure 5 , panel B).

Tubular cell proliferation determined by PCNA staining was broadly disseminated in the outer medulla, exactly in the same area of tubular injury. In the ischemic group (G2),

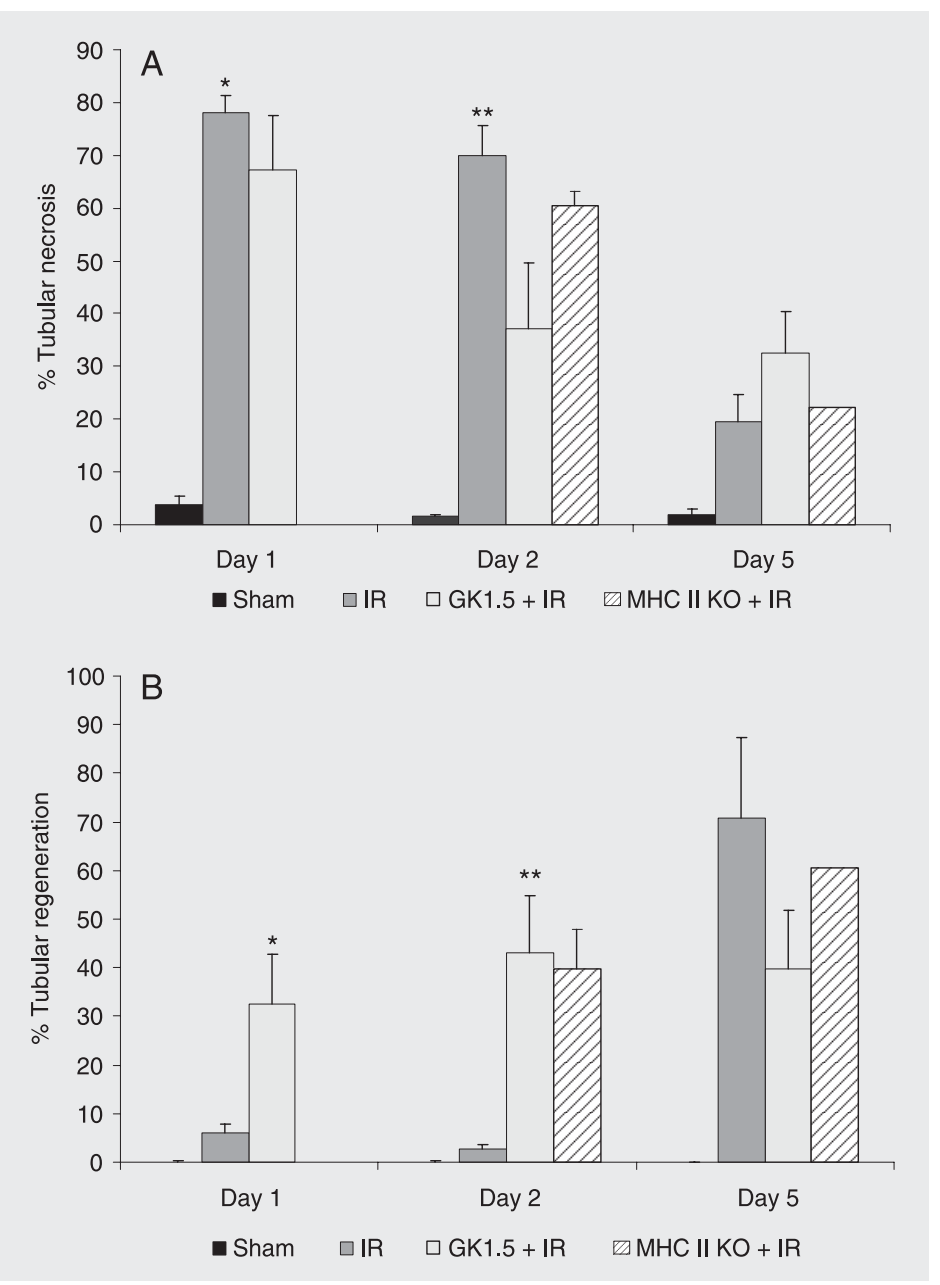

Figure 5. Morphometric analysis of tubular necrosis (A) and regeneration (B) areas in the outer medulla. $A, \mathrm{CD}^{+}$cell-depleted groups showed less extensive tubular necrosis than the ischemic group. $B$, Regeneration changes appeared early in groups in the anti-CD4+ mAb-treated and MHC II knock-out (MHC II KO) groups. Data are reported as percent as medians of 20 fields of each kidney section at magnification of 200X. H\&E. IR $=$ ischemia-reperfusion. ${ }^{*} \mathrm{P}<0.05$ for the ischemic group vs the GK1.5-treated group (ANOVA on ranks test, Dunn correction); ${ }^{*} \mathrm{P}<0.05$ for the ischemic group vs the GK1.5-treated and MHC II KO groups (ANOVA on ranks test, Dunn correction). we demonstrated PCNA-positive cells on days 1 (median of 53 cells/field) and 2 (34 cells/field) when the morphologic patterns of tubular regeneration were absent. These patterns greatly increased on day 5 (126 cells/filed). In contrast, the $\mathrm{CD}^{+}{ }^{+} \mathrm{T}$ celldepleted groups (G3 and G4) presented a significantly higher number of PCNA-positive cells on days 1 (G3 - 79 cells/filed) and 2 (G3 - 90.5 cells/field, G4 - 88.5 cells/field) in comparison to $\mathrm{G} 2$, similar to what was seen for tubular regeneration by morphometric analysis. In fact, PCNA staining of proliferating nuclei showed a positive correlation with the morphometric analysis of tubular regeneration $(\mathrm{R}=0.74, \mathrm{P}<0.0001)$. In the sham group, necrotic and regeneration changes were minimal.

In conclusion, in transient or sustained absence of $\mathrm{CD}^{+} \mathrm{T}$ cells, ischemic kidneys led to less tubular necrosis and displayed an early tubular regeneration signal, detected by morphometric and PCNA staining analyses.

\section{Infiltration of $\mathrm{CD}^{+}{ }^{-}$and CD11b-positive cells in renal tissue after ischemia-reperfusion}

Kidney tissues from sham-operated animals stained poorly for CD4 or CD11b markers. After 1 and 2 days of reperfusion, an increased number of interstitial infiltrating CD11b-positive cells was found in the outer medulla in all groups subjected to IR. They significantly differed from the sham group but not amongst themselves, regardless if they were $\mathrm{CD}^{+} \mathrm{T}$ cell-depleted or not (Figure 6 , panel A). Five days after ischemia, knockout animals had a decreased number of infiltrating CD11b-positive cells (9 cells/ field) compared to ischemic (24 cells/field) and GK1.5 mAb-treated (23.5 cells/field) groups $(\mathrm{P}<0.05)$.

IR injury resulted in infiltration of CD4positive cells in the renal tissue mainly on the second day after the insult (Figure 6, panel $\mathrm{B})$. In contrast, in $\mathrm{CD}^{+} \mathrm{T}$ cell-de- 
pleted animals (G3), this infiltration was delayed to three days, coinciding with the peripheral repopulation of $\mathrm{CD}^{+} \mathrm{T}$ lymphocytes. On day 2, when IR animals (G2) had an increased degree of tubular necrosis and increased renal dysfunction, groups 3 and 4 (depleted groups) showed the lowest levels of infiltrating $\mathrm{CD}^{+} \mathrm{T}$ cells in inflamed renal areas.

Gene transcript analyses in renal tissue after ischemia-reperfusion injury

Although substantial data in the literature indicate a role for T cells in IR injury, the mechanisms implicated are unclear regarding the action of cytokines. $\mathrm{CD} 4^{+} \mathrm{T}$ cells can provide help to $\mathrm{CD} 8^{+} \mathrm{T}$ cells that ultimately can become cytotoxic and to macrophages and NK cells, amplifying the immune response to self-tissues. Thus, we also investigated the role of the Th1 cytokine, $\mathrm{IFN}-\gamma$, and the $\mathrm{CD} 8^{+} \mathrm{T}$ cell-related cytolytic molecule, granzyme B. In addition, we analyzed the constant domain of the $\mathrm{BC}$ as a marker of the presence of $T$ cells. Gene expression of the constant domain of the $\mathrm{BC}$, IFN- $\gamma$ and granzyme B was semi-quantified by RT-PCR in renal tissue, normalized against an internal control, $B$-actin (for $B C$ and IFN- $\gamma$ ) or BC (granzyme B).

In the ischemic group, a high expression of $B C$ mRNA was detected on day 2 after IR injury ( 0.19 arbitrary units $v s 0.006$ and 0.06 on days 1 and 5 , respectively). In the $\mathrm{CD} 4^{+} \mathrm{T}$ cell-depleted groups, its level was hardly detected (all behind the level of 0.1 arbitrary units). This profile of $\mathrm{BC}$ mRNA expression in the ischemic group correlated with the CD4 staining seen by immunohistochemistry, both peaking on day 2 .

Despite the $\mathrm{CD}^{+}{ }^{+} \mathrm{T}$ depletion, there were no significant changes in IFN- $\gamma$ mRNA expression in the three groups submitted to IR, but these groups exhibited higher values of IFN- $\gamma$ mRNA than those detected in sham animals. Granzyme B mRNA expression was quite similar in all groups. They all showed a progressive increase in its levels from day 1 (0.23 units in ischemic group, 0.66 units in GK1.5-treated group), achieving the highest values on day $5(0.81,0.99,0.88$ units in ischemic, GK1.5-treated and MHC class II knock-out groups, respectively).

\section{Discussion}

$\mathrm{CD} 4^{+} \mathrm{T}$ cell infiltration has been well described in post-ischemic tissues $(6-8,11,23,24)$ but there are very few studies directly demon-

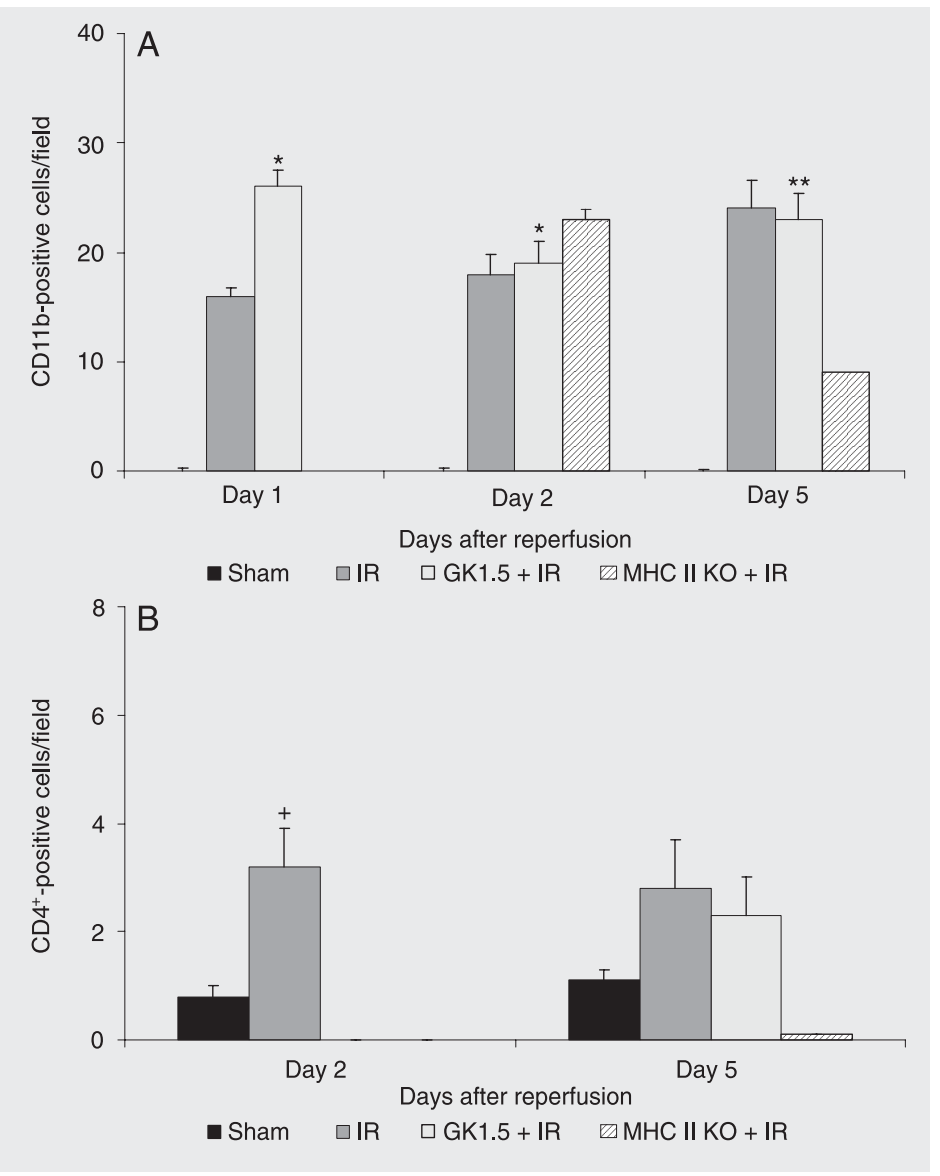

Figure 6. Immunohistochemistry of CD11b (A) and $\mathrm{CD} 4^{+}$(B) cells. $A$, On day 2 , groups submitted to renal ischemia exhibited more CD11b-positive cells than the sham group ( ${ }^{*} P<0.05$ ); on day 5 the knockout group had fewer positive cells than the ischemic and anti-CD4+-mAb-treated group $\left({ }^{\star \star} P<0.05\right)$. $B$, Ischemic group showed more CD4-positive cells than other groups on day $2\left({ }^{+} P<0.05\right)$. $\mathrm{IR}=$ ischemia-reperfusion. ${ }^{*} \mathrm{P}<0.05$, sham $v s$ the ischemic, GK1.5 and knockout groups; ${ }^{* *} P<0.05$, knockout group vs ischemic and GK1.5 group; ${ }^{+} \mathrm{P}<0.05$, ischemic vs other groups (ANOVA on ranks test, Dunn correction). 
strating the role of $\mathrm{T}$ lymphocytes in renal IR injury. Better long-term survival and less acute and chronic renal dysfunction have been reported after blockade of the B7:CD28/CD152 pathway $(7,11,15,16)$ in a rodent IR model. Rabb et al. (17) found diminished renal impairment in a model of 30-min ischemia followed by reperfusion in mice genetically deficient in $\mathrm{CD}^{+}$and $\mathrm{CD}^{+}{ }^{+} \mathrm{T}$ lymphocytes. Recently, the same group showed that reconstitution with $\mathrm{CD}^{+}{ }^{+} \mathrm{T}$ cells in $\mathrm{CD} 4{ }^{+} \mathrm{T}$ cell knockout mice reversed this effect $(17,18)$. These studies and our data indicate that mainly $\mathrm{CD}^{+}$ $\mathrm{T}$ cell subsets play a key role in renal injury following IR.

In the present study, we demonstrated a substantial reduction of renal IR injury in $\mathrm{CD}^{+}{ }^{+} \mathrm{T}$ cell-depleted mice compared to wildtype normal mice. The acute and transient depletion with GK1.5 mAb promoted similar results in genetically $\mathrm{CD}^{+}{ }^{+} \mathrm{T}$ cell-depleted mice, even with incomplete depletion 24 and $48 \mathrm{~h}$ after the insult, emphasizing the importance of a $\mathrm{T}$ cell subset in this very early phenomenon. Protection from renal IR injury by $\mathrm{CD} 4^{+} \mathrm{T}$ cell depletion was demonstrated by lower levels of serum urea and higher survival 5 days after IR in the depleted groups (G3 and G4) compared to IR mice (G2). This increased animal survival in $\mathrm{CD}^{+}{ }^{+} \mathrm{T}$ cell-depleted mice is probably due to a less serious impairment of renal function, since there were no deaths in sham-control mice.

We also quantitatively assessed the intensity of tubular necrosis and regeneration at both time points in the outer medulla, where the nephron segments most affected by IR injury are located. The $\mathrm{CD} 4{ }^{+} \mathrm{T}$ celldepleted groups had significantly less tubular injury in the outer medulla than normal mice since a smaller area of tubular necrosis and regeneration changes were present earlier after IR. This early regeneration profile was confirmed by a greater number of PCNApositive cells in $\mathrm{CD}^{+} \mathrm{T}$-depleted cells when compared to untreated control IR mice. The tubular regeneration pattern is not frequently exploited in experimental IR studies. It was possible to do in our study because we included day 5 after the reperfusion, when we could evaluate mice that survived to IR episode. Marques et al. (25) also demonstrated that in Th1-immune response-deficient mice, in the same model of renal IR, the attenuated tubular injury was linked to a precocious tubular regeneration.

As demonstrated by immunohistochemistry, CD4-positive cellular infiltration was greater on day 2 after reperfusion, coinciding with a higher expression of $\mathrm{C} \beta$ mRNA and peak urea levels in the ischemic group. This pattern is consistent with the studies by De Greef et al. (11) and Ysebaert et al. (24) using rat models of renal IR injury. In those studies $\mathrm{T}$ cell infiltration in the outer stripe of the outer medulla peaked after $24 \mathrm{~h}$, also coinciding with the highest creatinine levels after IR. The CD11b-positive cell infiltrate (macrophages, NK cells and dendritic cells) in the post-ischemic kidney was not significantly affected by $\mathrm{CD} 4^{+} \mathrm{T}$ cell depletion in our mouse IR model. Burne et al. (18) reported similar results in $\mathrm{CD}^{+} \mathrm{T}$ cell-deficient mice, i.e., they found no significant difference in the amount of macrophages or neutrophils infiltrating the kidney after 30 min of renal ischemia. These data support the hypothesis that $\mathrm{CD} 4^{+} \mathrm{T}$ cells act on IR injury despite recruitment and infiltration of this kind of inflammatory cells.

The increase in the expression of IFN- $\gamma$ mRNA in kidney tissues after IR injury has been described by others $(6,8,9,26)$. In our study, $\mathrm{CD} 4^{+} \mathrm{T}$ cell depletion, in addition to attenuating renal dysfunction, did not significantly alter the intensity of IFN- $\gamma$ mRNA expression. This suggests that IFN $-\gamma$ mRNA up-regulation in post-ischemic tissue is not directly linked to renal injury. In vivo neutralizing IFN- $\gamma$ with mAbs reduced MHC molecule expression but produced no improvement in renal dysfunction in a 60-min model of renal ischemia (26). Yokota et al. (27) also found no improvement in renal 
dysfunction in IFN- $\gamma$ knockout mice submitted to $35 \mathrm{~min}$ of ischemia. NK or T cells may be responsible for production of IFN- $\gamma$ after tissue injury. Our results suggest that NK cells may be responsible for the production of IFN- $\gamma$ since IFN- $\gamma$ persisted in a CD4 ${ }^{+} \mathrm{T}$ cell-depleted milieu and the abrogation of renal injury occurred independently of the IFN- $\gamma$ levels. The expression of granzyme B mRNA, a measure of cytotoxic effector mechanisms by $\mathrm{CD} 8^{+} \mathrm{T}$ lymphocytes, was similar in the groups studied, supporting the fact that renal IR injury is independent of this cell population $(18,24)$.

The pathways by which $\mathrm{T}$ cells might mediate renal IR injury are not easily determined on the basis of concepts of classical immunology. $T$ cell activation is a mandatory step in $\mathrm{T}$ cell-dependent immune responses. Activation of naive $\mathrm{T}$ cells has traditionally been demonstrated to require recognition by $\mathrm{T}$ cell receptors of a foreign antigen bound to self-MHC molecules in the presence of appropriate co-stimulatory signals by an antigen-presenting cell. We could not investigate this in our study because we cannot easily detect any foreign antigen present in renal IR injury that would activate T cells by classical pathways. Self-molecules could be modified due, for example, to oxidation by reactive oxygen species produced during the IR injury process (28), and their modified structure could then be recognized as foreign by the immune system $(3,23)$. In the absence of an appropriate antigen, activation of $\mathrm{T}$ lymphocytes might occur via an antigen-independent pathway. The chemokine RANTES has been shown to directly activate T cells $(29,30)$. Since RANTES upregulation has already been described in postischemic renal tissue $(7,31,32)$ and its blockade has attenuated renal IR dysfunction (10), direct activation of T cells by RANTES may be an attractive mechanism of renal IR injury. Another hypothesis, introduced by the "danger model", assumes that driving forces for an immune response are not the recogni- tion of foreign antigens but the recognition of danger (33). The tissue relays alarm signals to the local sentries, the antigen-presenting cells, to initiate immune responses. Some experimental studies have already investigated these mechanisms in models of IR injury $(34,35)$.

The most striking result revealed by our study is the important reduction of IR injury quite similar in the acute and in the genetically $\mathrm{CD}^{+} \mathrm{T}$ cell-depleted animals. The MHC class II knockout animals have an established $\mathrm{CD}^{+} \mathrm{T}$ cell depletion greater than $95 \%$. Since the GK1.5 mAb-depleted group was profoundly deficient in $\mathrm{CD} 4^{+} \mathrm{T}$ cells (less than $5 \%$ of normal) as early as during the first $24 \mathrm{~h}$ after the IR insult, this early period may be considered to be the critical phase when $\mathrm{CD} 4^{+} \mathrm{T}$ cells participate in the IR injury process. In view of the time necessary for the specific $\mathrm{T}$ cell immune response to occur and our results indicating unchanged CD11b infiltration and unmodified mRNA expression of granzyme B and IFN- $\gamma$, it appears that $\mathrm{CD} 4^{+} \mathrm{T}$ cells can participate in IR injury in a non-antigen-specific way. De Greef et al. (11) also clearly demonstrated $\mathrm{T}$ cell adherence a few hours after IR in the outer medulla post-capillary venules of ascending vasa recta, possibly acting by physical obstruction of these vessels and contributing to vascular congestion and the "no-reflow" phenomenon. The blockade of the CD28-B7 co-stimulatory pathway was able to neutralize this $\mathrm{T}$ cell adherence and to reduce renal impairment after IR.

The present study shows that an acute and transient $\mathrm{CD}^{+} \mathrm{T}$ lymphocyte depletion significantly limited renal dysfunction, mortality and tubular injury in a mouse model of IR, similar to what is observed in chronic and sustained long-term $\mathrm{CD} 4{ }^{+} \mathrm{T}$ cell depletion. These findings implicate a $\mathrm{CD} 4^{+}$subset of $\mathrm{T}$ lymphocytes as key mediators of early inflammatory responses after renal IR injury. It is not known if T cells act by mediating or amplifying renal injury. 


\section{References}

1. Boros P, Bromberg JS. New cellular and molecular immune pathways in ischemia/reperfusion injury. Am J Transplant 2006; 6: 652658.

2. Perico N, Cattaneo D, Sayegh MH, Remuzzi G. Delayed graft function in kidney transplantation. Lancet 2004; 364: 1814-1827.

3. Chapman JR, O'Connell PJ, Nankivell BJ. Chronic renal allograft dysfunction. J Am Soc Nephrol 2005; 16: 3015-3026.

4. Thadhani R, Pascual M, Bonventre JV. Acute renal failure. $N$ Engl J Med 1996; 334: 1448-1460.

5. Kelly KJ, Williams WW Jr, Colvin RB, Meehan SM, Springer TA, Gutierrez-Ramos JC, et al. Intercellular adhesion molecule-1-deficient mice are protected against ischemic renal injury. J Clin Invest 1996; 97: 1056-1063.

6. Takada M, Nadeau KC, Shaw GD, Marquette KA, Tilney NL. The cytokine-adhesion molecule cascade in ischemia/reperfusion injury of the rat kidney. Inhibition by a soluble P-selectin ligand. J Clin Invest 1997; 99: 2682-2690.

7. Takada M, Chandraker A, Nadeau KC, Sayegh MH, Tilney NL. The role of the $B 7$ costimulatory pathway in experimental cold ischemia/ reperfusion injury. J Clin Invest 1997; 100: 1199-1203.

8. Azuma H, Nadeau K, Takada M, Mackenzie HS, Tilney NL. Cellular and molecular predictors of chronic renal dysfunction after initial ischemia/reperfusion injury of a single kidney. Transplantation 1997; 64: 190-197.

9. Friedewald $\mathrm{JJ}$, Rabb H. Inflammatory cells in ischemic acute renal failure. Kidney Int 2004; 66: 486-491.

10. Shoskes DA. Effect of bioflavonoids quercetin and curcumin on ischemic renal injury: a new class of renoprotective agents. Transplantation 1998; 66: 147-152.

11. De Greef KE, Ysebaert DK, Dauwe S, Persy V, Vercauteren SR, Mey D, et al. Anti-B7-1 blocks mononuclear cell adherence in vasa recta after ischemia. Kidney Int 2001; 60: 1415-1427.

12. Rabb H. The $\mathrm{T}$ cell as a bridge between innate and adaptive immune systems: implications for the kidney. Kidney Int 2002; 61: 19351946.

13. Solez K, Morel-Maroger L, Sraer JD. The morphology of "acute tubular necrosis" in man: analysis of 57 renal biopsies and a comparison with the glycerol model. Medicine 1979; 58: 362-376.

14. Bonventre JV, Zuk A. Ischemic acute renal failure: an inflammatory disease? Kidney Int 2004; 66: 480-485.

15. Chandraker A, Takada M, Nadeau KC, Peach R, Tilney NL, Sayegh $\mathrm{MH}$. CD28-b7 blockade in organ dysfunction secondary to cold ischemia/reperfusion injury. Kidney Int 1997; 52: 1678-1684.

16. Ames JB, Laskowski IA, Dong VM, Gasser M, Sayegh MH, Tilney NL. A signaling anti-CD28 monoclonal antibody (JJ319) mitigates early renal dysfunction secondary to ischemia/reperfusion injury. $J$ Am Soc Nephrol 2000; 11: 585 (Abstract).

17. Rabb H, Daniels F, O'Donnell M, Haq M, Saba SR, Keane W, et al. Pathophysiological role of $\mathrm{T}$ lymphocytes in renal ischemia-reperfusion injury in mice. Am J Physiol Renal Physiol 2000; 279: F525F531.

18. Burne MJ, Daniels F, El Ghandour A, Mauiyyedi S, Colvin RB, O'Donnell MP, et al. Identification of the CD4(+) T cell as a major pathogenic factor in ischemic acute renal failure. J Clin Invest 2001; 108: $1283-1290$.

19. Grusby MJ, Johnson RS, Papaioannou VE, Glimcher LH. Depletion of CD4+ T cells in major histocompatibility complex class II-deficient mice. Science 1991; 253: 1417-1420.

20. Vieira JM Jr, Mantovani E, Rodrigues LT, Delle H, Noronha IL, Fujihara CK, et al. Simvastatin attenuates renal inflammation, tubular transdifferentiation and interstitial fibrosis in rats with unilateral ureteral obstruction. Nephrol Dial Transplant 2005; 20: 1582-1591.

21. O'Connell PJ, Pacheco-Silva A, Nickerson PW, Muggia RA, Bastos $M$, Kelley VR, et al. Unmodified pancreatic islet allograft rejection results in the preferential expression of certain $\mathrm{T}$ cell activation transcripts. J Immunol 1993; 150: 1093-1104.

22. Yokota N, Daniels F, Crosson J, Rabb H. Protective effect of T cell depletion in murine renal ischemia-reperfusion injury. Transplantation 2002; 74: 759-763.

23. Land WG. The role of postischemic reperfusion injury and other nonantigen-dependent inflammatory pathways in transplantation. Transplantation 2005; 79: 505-514.

24. Ysebaert DK, De Greef KE, Vercauteren SR, Ghielli M, Verpooten GA, Eyskens EJ, et al. Identification and kinetics of leukocytes after severe ischaemia/reperfusion renal injury. Nephrol Dial Transplant 2000; 15: 1562-1574.

25. Marques VP, Goncalves GM, Feitoza CQ, Cenedeze MA, Fernandes Bertocchi AP, Damiao MJ, et al. Influence of TH1/TH2 switched immune response on renal ischemia-reperfusion injury. Nephron Exp Nephrol 2006; 104: e48-e56.

26. Daemen MA, van't Veer C, Wolfs TG, Buurman WA. Ischemia/ reperfusion-induced IFN-gamma up-regulation: involvement of IL12 and IL-18. J Immunol 1999; 162: 5506-5510.

27. Yokota N, Burne-Taney M, Racusen L, Rabb H. Contrasting roles for STAT4 and STAT6 signal transduction pathways in murine renal ischemia-reperfusion injury. Am J Physiol Renal Physiol 2003; 285: F319-F325.

28. Niemela O, Parkkila S, Yla-Herttuala S, Halsted C, Witztum JL, Lanca $\mathrm{A}$, et al. Covalent protein adducts in the liver as a result of ethanol metabolism and lipid peroxidation. Lab Invest 1994; 70: 537-546.

29. Bacon KB, Premack BA, Gardner P, Schall TJ. Activation of dual T cell signaling pathways by the chemokine RANTES. Science 1995; 269: 1727-1730.

30. Appay V, Dunbar PR, Cerundolo V, McMichael A, Czaplewski L, Rowland-Jones S. RANTES activates antigen-specific cytotoxic T lymphocytes in a mitogen-like manner through cell surface aggregation. Int Immunol 2000; 12: 1173-1182.

31. Ishibashi N, Weisbrot-Lefkowitz M, Reuhl K, Inouye M, Mirochnitchenko O. Modulation of chemokine expression during ischemia/reperfusion in transgenic mice overproducing human glutathione peroxidases. J Immunol 1999; 163: 5666-5677.

32. Lemay S, Rabb H, Postler G, Singh AK. Prominent and sustained up-regulation of gp130-signaling cytokines and the chemokine MIP2 in murine renal ischemia-reperfusion injury. Transplantation 2000; 69: 959-963.

33. Matzinger P. An innate sense of danger. Ann N Y Acad Sci 2002; 961: 341-342.

34. Kim BS, Lim SW, Li C, Kim JS, Sun BK, Ahn KO, et al. Ischemiareperfusion injury activates innate immunity in rat kidneys. Transplantation 2005; 79: 1370-1377.

35. Shen XD, Ke B, Zhai Y, Gao F, Busuttil RW, Cheng G, et al. Toll-like receptor and heme oxygenase-1 signaling in hepatic ischemia/reperfusion injury. Am J Transplant 2005; 5: 1793-1800. 